\title{
Penggunaan buku komik "bahasa Indonesia bagi penutur asing (BIPA) 1" dan pengaruhnya terhadap hasil belajar peserta BIPA
}

\author{
Randi Ramliyana*), \\ Universitas Indraprasta PGRI \\ *) Correspondences author: Jl. Raya Tengah No.80, RT.6/RW.1, Gedong, Kec. Ps. Rebo, Kota Jakarta Timur, Daerah Khusus \\ Ibukota Jakarta 13760; \\ e-mail randi.ramliyana@gmail.com
}

\begin{abstract}
Indonesian Language Learning for Foreign Speakers (BIPA) is interesting because Indonesian language becomes the second language learning for BIPA participants. Many obstacles are happened during learning BIPA, one of communication problem between teacher and participant. Communication problem in delivering material BIPA class can overcome with visual language. Visual language will be made in the form of comics as and teach BIPA. Comics as a medium of learning has long been applied to give a positive impact during the learning process Comic media in addition to fun, also always linked can increase interest in reading, and develop vocabulary in the language used comic As a first step to arouse interest in reading especially those who do not like reading In addition to comics also improve all other language skills, such as talking and listening. Comics is able to package all learners with a fun language skills. So, comics have a close related with language learning, because it is always associated with improving language skills therefore, research aims to design the book in the form of comic on learning BIPA language. Researchers hope this research will be useful for the world of language education, especially BIPA, in Indonesia and provide new solutions by using comics as a fun learning media and able to increase interest and motivation to learn BIPA participants.
\end{abstract}

Key Words: BIPA, comics, design, textbook.

This work is licensed under a Creative Commons Attribution-ShareAlike 4.0 International License

\section{Pendahuluan}

Program Bahasa Indonesia bagi Penutur Asing (BIPA) adalah sebuah ladang subur yang tak bertuan. Siapa pun dapat menggarapnya. Program BIPA masih merupakan hal baru dalam dunia pendidikan, khususnya di Indonesia. Belum adanya standarisasi nasional atau kurikulum nasional BIPA menyebabkan keberagaman pada program BIPA yang ada di Indonesia.

Keberagaman dalam kurikulum yang digunakan menyebakan setiap program BIPA memiliki kebijakan tersendiri dalam menentukan tingkatan kemahiran peserta BIPA. Ada program BIPA yang mengacu pada The Common European of Reference for Language (CEFR) atau pada Uji Kemahiran Berbahasa Indonesia (UKBI). Bahkan ada yang membuat sendiri acuan dalam program BIPA tersebut. Salah satu lembaga yang menyelenggarakan program BIPA adalah Universitas Trisakti.

BIPA Universitas Trisakti berada di bawah Pusat Bahasa dan Budaya Universitas Trisakti yang bekerja sama dengan Kampung Bahasa Bloombank. Kampung Bahasa Bloombank telah berdiri sejak tiga tahun lalu dan fokus di BIPA. Kampung Bahasa Bloombank telah membuat kurikulum dan silabus BIPA sendiri. Selain itu, Kampung Bahasa Bloombank juga telah membuat buku ajar BIPA yang terdiri dari empat tingkatan, yaitu prapemula, pemula, madya, dan mahir.

Indonesia merupakan negara berkembang yang memiliki banyak kekayaan alam yang harus dikelola dengan baik. Selain itu, pertumbuhan perekonomian di Indonesia terus berkembang dan sangat menjanjikan. Hal itulah yang membuat Indonesia menjadi negara tujuan untuk bekerja, berbisnis, dan bersekolah. Seiring dengan hal tersebut, bahasa Indonesia pun terkena imbasnya, yakni semakin banyak dipelajari oleh penutur asing. 
Bahasa Indonesia merupakan salah satu bahasa di dunia yang berkembang pesat pada abad 20-an. Pembelajaran Bahasa Indonesia bagi Penutur Asing (BIPA) merupakan hal yang menarik, karena bahasa Indonesia menjadi pembelajaran bahasa kedua bagi para peserta BIPA. Pembelajaran BIPA terus mengalami peningkatan baik di dalam maupun luar negeri. Semakin banyaknya program BIPA dibuka semakin banyak pula kendala yang ditemukan selama proses pembelajaran berlangsung, salah satunya adalah masalah komunikasi antara pengajar dan peserta.

Permasalahan komunikasi dalam menyampaikan materi biasanya terjadi pada kelas BIPA di dalam negeri. Para pengajar BIPA tidak menguasai seluruh bahasa para peserta, hanya bisa menggunakan bahasa Inggris pada umumnya. Selain itu, beberapa siswa dari negara-negara yang tidak menggunakan bahasa Inggris sebagai bahasa pertama mereka juga menjadi salah satu penyebab kendala komunikasi dapat terjadi. Namun, permasalah komunikasi tersebut telah coba diatasi oleh peneliti dalam penelitiannya sebelumnya mengenai penggunaan komik di dalam kelas BIPA.

Komik sebagai media pembelajaran sudah lama diterapkan dan memberikan dampak yang positif selama proses pembelajaran. Media komik selain menyenangkan, juga selalu dikaitkan dapat meningkatkan minat membaca, serta mengembangkan perbendaharaan kosakata dalam berbahasa. Komik digunakan sebagai langkah awal untuk membangkitkan minat membaca peserta, terutama yang tidak suka membaca. Selain karena komik menghibur, menyenangkan dan edukatif, komik juga merupakan jembatan untuk membaca buku yang lebih serius. Jadi, disimpulkan bahwa media komik memiliki kaitan yang erat dengan pembelajaran bahasa, karena selalu dikaitkan dengan peningkatan keterampilan berbahasa. Jika membicarakan tentang media komik yang berpengaruh penting dalam peningkatan minat membaca peserta, secara otomatis kemampuan peserta dalam menulis pun akan meningkat. Oleh sebab itu, penelitian ini bertujuan untuk mendeskripsikan perancangan buku Komik BIPA 1 sebagai buku komik BIPA pertama yang dibuat di seluruh dunia. Peneliti berharap penelitian ini akan berguna bagi dunia pendidikan bahasa, terutama BIPA, di Indonesia dan memberikan solusi baru dengan menggunakan komik sebagai media pembelajaran yang menyenangkan dan tepat bagi semua peserta.

\section{Media Pembelajaran}

Media berasal dari bahasa Latin yang merupakan bentuk jamak dari medium yang berarti perantara atau pengantar, yaitu perantara atau pengantar sumber pesan dengan penerima pesan. Media pembelajaran interaktif adalah sebuah metode pembelajaran berbasis teknologi informasi dan komunikasi. Media pembelajaran interaktif merupakan media penyampaian pesan antara pengajar dan peserta yang memungkinkan komunikasi antara manusia dan teknologi melalui sistem dan infrastruktur berupa program aplikasi serta pemanfaatan media elektronik sebagai bagian dari metode edukasinya.

Media pembelajaran dewasa ini sudah merupakan kewajiban yang harus disiapkan oleh para pengajar dalam upaya menciptakan suasana pembelajaran yang menarik, menyenangkan, menggairahkan, dan menggugah. Dengan menggunakan media pembelajaran, interaksi antara pengajar dan peserta akan lebih efektif karena mereka bisa berkomunikasi satu sama lain dan yang terpenting mampu berperan secara aktif memanfaatkan media pembelajaran dalam setiap kegiatan belajar mengajar.

Media pembelajaran sebaiknya diciptakan sesuai dengan kebutuhan peserta. Kesempurnaan media pembelajaran akan tercipta apabila pengajar mampu membuat dalam bentuk manual dan dalam bentuk elektronik. Media pembelajaran manual dapat dibuat mulai dari bahan yang sederhana hingga bahan yang rumit. Hal tersebut bergantung pada kemampuan pengajar untuk menyiapkan bahan dan mengemasnya secara baik. Hal tersebut sejalan dengan apa yang dikatakan oleh Edgar Dale dalam Daryanto, Penggunaan media pembelajaran seringkali menggunakan prinsip Kerucut Pengalaman yang membutuhkan media, seperti buku teks, bahan belajar yang dibuat oleh guru, dan audio-visual.

\section{Manfaat Media Pembelajaran}

Media memiliki peranan penting dalam mengarahkan proses pembelajaran dan hasil yang diinginkan dalam pembelajaran. Manfaat dari media pembelajaran secara interaktif, antara lain sebagai berikut.

1. Penyampaian materi pembelajaran yang dapat diseragamkan

Media pembelajaran dapat membantu mengurangi perbedaan penafsiran antara pengajar dan peserta yang sedang belajar bahasa Indonesia di mana pun mereka berada. 
2. Proses pembelajaran menjadi lebih jelas dan menarik

Media dapat menciptakan suasana pembelajaran yang lebih menarik. Media mampu menampilkan informasi melalui suara, gambar, gerakan, dan warna baik secara alami maupun manipulasi. Keadaan ini akan sangat membantu pengajar untuk menciptakan suasana belajar menjadi lebih hidup, tidak monoton dan tidak membosankan.

3. Proses Pembelajaran menjadi lebih interaktif

Proses pembelajaran akan berhasil apabila terjadi interaksi yang efektif antara pengajar dan peserta. Dengan adanya media pembelajaran, proses interaktif selama pembelajaran dapat terwujud.

4. Efisiensi dalam waktu dan tenaga

Salah satu tolok ukur keberhasilan kegiatan belajar-mengajar adalah dengan mengefisienkan waktu dan tenaga seminimal mungkin, dapat mencapai tujuan belajar semaksimal mungkin. Hal ini cukup beralasan karena pengajar tidak perlu menjelaskan berulang-ulang. Dengan bantuan media pembelajaran, para peserta bisa lebih mudah memahami materi yang diajarkan.

5. Meningkatkan kualitas hasil belajar peserta

Media pembelajaran dapat meningkatkan kualitas hasil belajar peserta. Media pembelajaran yang baik adalah media yang mudah dipelajari dan dipahami oleh para peserta baik ketika di kelas maupun di luar kelas. Artinya media pembelajaran ini dapat juga dipraktikkan oleh para peserta tanpa didampingi oleh para pengajar. Dengan demikian, semakin sering para peserta memanfaatkan media pembelajaran akan semakin paham dalam menerima materi yang diajarkan sehingga kualitas hasil belajar dapat meningkat secara signifikan.

6. Media pembelajaran dapat menumbuhkan sikap positif peserta terhadap materi dan proses pembelajaran

Media pembelajaran yang baik adalah media yang dapat membantu para peserta lebih percaya diri terhadap keterampilan berbahasa yang dimiliki. Media pembelajaran akan sangat membantu para peserta dalam mengasah pikiran dan mengoptimalkan kemampuan masing-masing peserta sehingga tujuan pembelajaran dapat tercapai secara maksimal.

7. Mengubah peran pengajar ke arah yang lebih positif dan produktif

Membuat media pembelajaran adalah salah satu bukti kreativitas seorang pengajar. Ide-ide baru yang cemerlang akan ia tuangkan dalam bentuk media pembelajaran untuk membantu para peserta dalam memahami materi secara mudah. Inilah yang disebut dengan pengajar yang berpikir positif dan produktif. Selain itu, pengajar yang baik harus selalu memanfaatkan teknologi yang ada, itu sebabnya penguasaan multimedia mutlak diperlukan karena akan mempermudah para pengajar dalam mempraktikkan media pembelajaran bersama dengan para peserta.

\section{Keuntungan Media Pembelajaran}

Media memiliki peranan penting dalam mengarahkan proses pembelajaran dan hasil yang diinginkan dalam pembelajaran. Kelebihan dari media pembelajaran secara interaktif, antara lain sebagai berikut.

1. Dapat memberikan pemahaman yang lebih dalam terhadap materi pembelajaran yang sedang dibahas, karena dapat menjelaskan konsep yang sulit atau rumit menjadi mudah atau lebih sederhana

2. Dapat menjelaskan materi pembelajaran atau objek yang abstrak (tidak nyata, tidak dapat dilihat langsung) menjadi konkrit (nyata dapat dilihat, dirasakan, atau diraba), seperti menjelaskan peredaran darah dan organ-organ tubuh manusia pada mata pelajaran Sains.

3. Membantu pengajar menyajikan materi pembelajaran menjadi lebih mudah dan cepat sehingga peserta pun mudah dipahami, lama diingat, dan mudah diungkapkan kembali.

4. Menarik dan membangkitkan perhatian, minat, motivasi, aktivitas, dan kreativitas belajar peserta, serta dapat menghibur peserta.

5. Memancing partisipasi peserta dalam proses pembelajaran dan memberikan kesan yang mendalam pada pikiran peserta.

6. Materi pembelajaran yang sudah dipelajari dapat diulang kembali (playback), misalnya menggunakan rekamana video, cakram padat (compact disk), tape recorder atau televisi. 
7. Dapat membentuk persamaan pendapat dan persepsi yang benar terahadap suatu objek, tetapi dalam bentuk nyata menggunakan media pembelajaran.

8. Menciptakan lingkungan belajar yang kondusif sehingga peserta dapat berkomunikasi dan berinteraksi dengan lingkungan tempat belajarnya sehingga memberikan pengalaman nyata dan langsung. Peserta didik mempelajari tentang jenis-jenis tumbuhan. Mereka langsung melihat, memegang, atau merasakan tumbuhan tersebut.

9. Membentuk sikap peserta (aspek afektif) dan meningkatkan keterampilan (psikomotor).

10. Peserta belajar sesuai dengan karakteristiknya, kebutuhan, minat, dan bakatnya baik secara individual, kelompok, maupun klasikal. Menghemat waktu, tenaga, dan pikiran.

\section{Komik}

Peneliti memilih komik sebagai media pada pembelajaran BIPA karena ia merupakan media yang menyenangkan dan dapat menjadi media edukatif selama proses pembelajaran berlangsung. Meskipun masyarakat masih beranggapan bahwa komik hanya cerita bergambar yang ringan dan menyenangkan. Banyak orang yang belum tahu definisi tentang komik. Oleh sebab itu, banyak yang mencoba mengemukakan definisi komik, di antaranya adalah sebagai berikut.

McCloud menjelaskan, Komik adalah gambar-gambar dan lambang-lambang lain yang terjuktaposisi dalam tuturan tertentu, bertujuan untuk memberikan informasi dan mencapai tanggapan estetis dari pembaca." Berkenan dengan pengertian tersebut, Harvey menyarankan, Pernyataan kombinasi berseni dari kata dan gambar harus terliput dalam semua definisi tentang komik". McCloud menambahkan bahwa kekuatan kata adalah bagian tak terpisahkan dari pesona karya seni yang disebut komik. Pendapat lain dikemukanan Sudjana dan Rivai, Komik dapat didefinisikan sebagai suatu bentuk kartun yang mengungkapkan karakter dan memerankan suatu cerita dalam urutan yang erat dihubungkan dengan gambar dan dirancang untuk memberikan hiburan kepada para pembaca. Selanjutnya Masdiono menjelaskan, Komik adalah gamcer atau gambar bercerita atau sebuah dunia tutur gambar, suatu rentetan gambar yang bertutur menceritakan suatu kisah.

Sementara, Eisner mendefinisikan teknis dan struktur komik sebagai sequential art, Susunan gambar dan kata-kata untuk menceritakan sesuatu atau mendramatisasi suatu ide. Berdasarkan uraian di atas, dapat dikatakan bahwa para ahli masih belum sependapat mengenai definisi komik, sebagian di antaranya berpendapat bahwa bentuk cetaknya perlu ditekankan, yang lain lebih mementingkan kesinambungan gambar dan kata, dan sebagian lain lebih menekankan sifat kesinambungannya (sequential).

Berdasarkan beberapa definisi tentang komik di atas, peneliti menyimpulkan bahwa komik adalah salah satu karya sastra bernilai estetis yang terdiri atas perpaduan antara gambar dan kata yang membentuk sebuah cerita.

Selain itu, komik bertujuan untuk memberikan informasi dan hiburan kepada pembaca. Daya tarik berbagai jenis komik mengikuti pola yang dapat diprediksikan. Hurlock berpendapat bahwa anak-anak usia sekolah menyukai komik karena beberapa hal di antaranya:

1. melalui identifikasi dengan karakter di dalam komik, anak memperoleh kesempatan yang baik untuk mendapat wawasan mengenal masalah pribadi dan sosialnya. Hal ini akan membantu memecahkan masalahnya,

2. komik menarik imajinasi anak dan rasa ingin tahu tentang masalah supranatural,

3. komik memberi anak pelarian sementara hirup-pikuk hidup sehari-hari,

4. komik mudah dibaca, bahkan anak yang kurang mampu membaca dapat memahami arti dari gambarnya,

5. karena komik tidak mahal dan juga ditayangkan di televisi sehingga semua anak mengenalnya,

6. karena banyak komik yang menggairahkan, misterius, dan lucu, komik mendorong anak untuk membaca yang tidak banyak diberikan buku lain,

7. bila berbentuk serial, komik memberi sesuatu yang diharapkan,

8. dalam komik, tokoh sering melakukan atau mengatakan hal-hal yang tidak berani mereka lakukan sendiri, walaupun mereka ingin melakukannya, ini memberikan kegembiraan, 
34 Penggunaan buku komik "bahasa Indonesia bagi penutur asing (BIPA) 1" dan pengaruhnya terhadap hasil belajar peserta BIPA

9. tokoh dalam komik sering kuat, berani, dan berwajah tampan, jadi memberikan tokoh pahlawan bagi anak untuk mengidentifikasikannya,

10. gambar dalam komik berwarna-warni dan cukup sederhana untuk dimengerti anak-anak.

Oller mengatakan, Teks (bentuk ujaran dan tulis dalam wacana) yang lebih tidak sengaja tersusun dapat disimpan dan diingat kembali lebih mudah daripada bahan yang kurang tersusun secara tidak sengaja.

Dengan kata lain, hal itu lebih mudah bagi peserta belajar bahasa jika mereka diberikan kalimat terhubung yang memiliki struktur logis dan alur cerita, bukannya terputus, frase diatur secara acak. Kosakata dan bahasa dapat dipelajari dalam konteks. Namun, Oller selangkah lebih maju dan menyatakan bahwa konteks itu sendiri tidak cukup. Hal yang terpenting adalah dialog atau teks harus memiliki struktur logis dan simpulan yang logis. Dengan cara ini, peserta dapat mengikuti alur cerita selangkah demi selangkah dan dapat mengingat struktur lebih mudah karena logika membantu mereka.

Teori Oller dapat diterapkan pada penggunaan komik dalam pengajaran bahasa. Komik memiliki alur cerita yang mampu membawa peserta pada simpulan dari materi yang dibawakan. Dengan cara itu, peserta termotivasi melanjutkan untuk membaca dan kembali lebih terlibat ke dalam isi daripada bahasa. Konsekuensinya, peserta akan lebih asyik mengetahui apa yang akan terjadi, bagaimana akhir dari cerita (rasa pensaran mereka muncul), dan akan mengingat bentuk kata, ekspresi, dan gramatikal lebih mudah.

Brown menunjukkan bahwa, Internalisasi terbaik dari kosakata berasal dari pertemuan (komprehensi dan produksi) kata dalam konteks sekitarnya." Dengan cara ini, peserta akan mengasosiasikan kata dengan konteks sebenarnya dan mereka dapat mengingat dan menggunakannya lebih baik daripada hanya mempelajari setah kata dan maknanya secara korespondensinya. Selain kosakata, kompetensi tata bahasa dapat ditingkatkan dengan baik. Dengan bantuan komik, tata bahasa baru dapat diperkenalkan dan dipraktikan, dan sejak materi tata bahasa ditanamkan di dalam cerita dengan struktur yang logis, peserta akan mampu mengingat lebih baik selanjutnya.

Karakteristik komik juga mampu meningkatkan motivasi (khususnya komik yang berwarna). Hal yang lebih penting jika kata, ekspresi, atau konsep disertai oleh gambar (visual gambar dalam satu pikiran), selanjutnya peserta akan lebih mudah menghafal dan mengingat lebih mudah.

Fakta bahwa visual komik juga berkontribusi untuk meningkatkan kompetensi komunikasi. Di dalam komik, kehidupan seperti situasi dan ekspresi yang digunakan dalam percakapan, bahasa seharihari, sebagai contoh, idiom, pengurangan bentuk, bahasa slang, dan ekspresi yang membutuhkan berbagai pengetahuan budaya. Konsekuensinya, komik membantu peserta menangani percakapan bahkan dalam situasi informal. Keuntungan lainnya dari visual komik adalah gestur dan bahasa tubuh dari para tokoh. Kontribuasi ini untuk membangun kompetensi komunikasi, yang artinya termasuk ke dalam komunikasi nonverbal.

\section{Metode}

Dalam suatu penelitian diperlukan metode atau pendekatan yang berguna untuk memecahkan suatu permasalahan yang diteliti. Pemilihan metode yang tepat turut menentukan keberhasilan sesuatu penelitian, karena dalam metode penelitian dapat terlihat jelas mengenai tahapan-tahapan pelaksanaan, serta arah dan tujuan dari penelitian. Metode penelitian dapat diartikan sebagai cara ilmiahuntuk mendapatkan data yang valid dengan tujuan dapat ditemukan, dikembangkan, dan dibuktikan, suatu pengetahuan tertentu sehingga pada gilirannya dapat digunakan untuk memahami, memecahkan, dan mengantisipasi suatu masalah.

Dalam hal ini penelitian yang dilakukan menggunakan metode eksperimen, karena penelitian ini digunakan untuk mengujicobakan sebuah buku ajar Bahasa Indonesia bagi Penutur Asing (BIPA) berbentuk komik, guna mencapai tujuan pembelajaran. Metode penelitian eksperimen dapat diartikan sebagai metode penelitian yang digunakan untuk mencari pengaruh perlakuan tertentu terhadap yang lain dalam kondisi yang terkendalikan. Pada penelitian ini diusahakan mencari pengaruh dari proses pembelajaran yang akan dilakukan terhadap siswa sebagai objek penelitian. Dalam hal ini, ketercapaian pembelajaran lebih ditekankan pada keterampilan siswa dalam berbahasa Indonesia pada tingkatan prapemula yang diberikan perlakuan menggunakan buku ajar BIPA berbetuk komik. 
Metode eksperimen yang digunakan dalam penelitian ini adalah metode quasi eksperimen. Hal tersebut disebabkan sampel yang digunakan hanya satu, tanpa adanya kelas kontrol atau kelas pembanding. Alasan menggunakan desin eksperimen ini, karena pada pelaksanaannya tidak menggunakan dua kelas, yaitu kelas kontrol dan kelas eksperimen. Hal tersebut dilakukan secara efektif untuk mencapai hasil yang maksimal.

\section{Pembahasan}

\section{Hasil pre-test dan post-test dan pengujian hipotesis}

Tabel 1. Skor Pre-Tes dan Pos-Tes Keterampilan Membaca

\begin{tabular}{|l|l|l|}
\hline No Responden & Skor Pre Tes & Skor Pos Test \\
\hline 1 & 40 & 60 \\
2 & 50 & 70 \\
3 & 60 & 70 \\
4 & 50 & 80 \\
5 & 70 & 80 \\
6 & 50 & 90 \\
7 & 50 & 80 \\
8 & 60 & 70 \\
9 & 60 & 60 \\
10 & 60 & 70 \\
\hline
\end{tabular}

Tabel 2 Skor Pre-Tes dan Pos-Tes Keterampilan Menulis

\begin{tabular}{|l|l|l|}
\hline No Responden & Skor Pre Tes & Skor Pos Test \\
\hline 1 & 50 & 60 \\
2 & 60 & 70 \\
3 & 70 & 70 \\
4 & 50 & 90 \\
5 & 80 & 90 \\
6 & 50 & 70 \\
7 & 60 & 80 \\
8 & 60 & 80 \\
9 & 50 & 70 \\
10 & 50 & 70 \\
\hline
\end{tabular}

Tabel 3 Skor Pre-Tes dan Pos-Test Keterampilan Menyimak

\begin{tabular}{|l|l|l|}
\hline No Responden & Skor Pre Tes & Skor Pos Test \\
\hline 1 & 50 & 60 \\
2 & 50 & 60 \\
3 & 60 & 70 \\
4 & 50 & 70 \\
5 & 70 & 80 \\
6 & 60 & 70 \\
7 & 60 & 90 \\
8 & 50 & 70 \\
9 & 50 & 70 \\
10 & 50 & 70 \\
\hline
\end{tabular}

Tabel 4 Skor Pre-Tes dan Pos-Test Keterampilan Berbicara 
36 Penggunaan buku komik "bahasa Indonesia bagi penutur asing (BIPA) 1" dan pengaruhnya terhadap hasil belajar peserta BIPA

\begin{tabular}{|l|l|l|}
\hline No Responden & Skor Pre Tes & Skor Pos Test \\
\hline 1 & 60 & 70 \\
2 & 40 & 70 \\
3 & 50 & 80 \\
4 & 50 & 90 \\
5 & 80 & 80 \\
6 & 60 & 80 \\
7 & 60 & 80 \\
8 & 50 & 70 \\
9 & 40 & 70 \\
10 & 60 & 70 \\
\hline
\end{tabular}

Selanjutnya dilakukan deskripsi data penelitian sebagai berikut.

Tabel 5 Deskriptif Statistik

Descriptive Statistics

Dependent Variable: Prestasi
\begin{tabular}{|ll|r|r|r|}
\hline MetodeBelajar & MetodeUjian & Mean & Std. Deviation & N \\
\hline Ceramah & Membaca & 55.00 & 8.498 & 10 \\
& Mendengar & 58.00 & 10.328 & 10 \\
& Menyimak & 55.00 & 7.071 & 10 \\
& Berbicara & 55.00 & 11.785 & 10 \\
& Total & 55.75 & 9.306 & 40 \\
\hline Komik & Membaca & 73.00 & 9.487 & 10 \\
& Mendengar & 75.00 & 9.718 & 10 \\
& Menyimak & 71.00 & 8.756 & 10 \\
& Berbicara & 76.00 & 6.992 & 10 \\
& Total & 73.75 & 8.679 & 40 \\
\hline Total & Membaca & 64.00 & 12.732 & 20 \\
& Mendengar & 66.50 & 13.089 & 20 \\
& Menyimak & 63.00 & 11.286 & 20 \\
& Berbicara & 65.50 & 14.318 & 20 \\
& Total & 64.75 & 12.726 & 80 \\
\hline
\end{tabular}

Dari tabel di atas, kita bisa menilai rata-rata nilai ujian berdasarkan ceramah dan komik. nilai rata-rata ujian kemampuan berbahasa membaca dengan metode ceramah sebesar 55,00 sedangkan nilai ujian kemampuan berbahasa membaca dengan metode komik sebesar 73,00 dan, nilai rata-rata ujian kemampuan berbahasa mendengar dengan metode ceramah sebesar 58,00 sedangkan nilai ujian kemampuan berbahasa mendengar dengan metode komik sebesar 75,00, nilai rata-rata ujian kemampuan berbahasa menyimak dengan metode ceramah sebesar 55,00 sedangkan nilai ujian kemampuan berbahasa menyimak dengan metode komik sebesar 71,00, nilai rata-rata ujian kemampuan berbahasa berbicara dengan metode ceramah sebesar 55,00 sedangkan nilai ujian kemampuan berbahasa berbicara dengan metode komik sebesar 76,00

Sebelum dilakukan pengujian hipotesis dilakukan uji normalitas diata dengan menggunakan uji Kolmorgov-Smirnov dengan hasil sebagai berikut..

Tabel 6. Uji Normalitas Data Keterampilan Membaca 
One-Sample Kolmogorov-Smirnov Test

\begin{tabular}{|ll|r|}
\hline & & $\begin{array}{r}\text { Unstandardiz } \\
\text { ed Residual }\end{array}$ \\
\hline Normal Parameters & a,b & Mean \\
& Std. Deviation & $0 \mathrm{E}-7$ \\
Most Extreme Differences & Absolute & 9.46428283 \\
& Positive & .209 \\
Kolmogorov-Smirnov Z & Negative & .209 \\
Asymp. Sig. (2-tailed) & & -.160 \\
\end{tabular}

a. Test distribution is Normal.

b. Calculated from data.

Berdasarkan hasil uji normalitas diatas dapat dilihat signifikansi 0,776 >0,05 makadapat disimpulkan data berdistribusi normal.

One-Sample Kolmogorov-Smirnov Test

\begin{tabular}{|ll|r|}
\hline & & $\begin{array}{r}\text { Unstandardiz } \\
\text { ed Residual }\end{array}$ \\
\hline $\mathrm{N}$ & 10 \\
Normal Parameters & Mean & $0 \mathrm{E}-7$ \\
Most Extreme Differences & Std. Deviation & 6.81320432 \\
& Absolute & .236 \\
Kolmogorov-Smirnov $Z$ & .236 \\
Asymp. Sig. (2-tailed) & Negitive & -.164 \\
\end{tabular}

a. Test distribution is Normal.

b. Calculated from data.

Tabel 7 Uji Normalitas Data Keterampilan Menulis

One-Sample Kolmogorov-Smirnov Test

\begin{tabular}{|ll|r|}
\hline & & $\begin{array}{r}\text { Unstandardiz } \\
\text { ed Residual }\end{array}$ \\
\hline $\mathrm{N}$ & Mean & 10 \\
Normal Parameters & $0 \mathrm{E}-7$ \\
Most Extreme Differences & Std. Deviation & 8.71354841 \\
& Absolute & .176 \\
& Positive & .176 \\
Kolmogorov-Smirnov $Z$ & Negative & -.124 \\
Asymp. Sig. (2-tailed) & & .556 \\
\hline
\end{tabular}

a. Test distribution is Normal.

b. Calculated from data.

Berdasarkan hasil uji normalitas diatas dapat dilihat signifikansi 0,917>0,05 makadapat disimpulkan data berdistribusi normal.

Tabel 8 Uji Normalitas Data Keterampian Menyimak 
38 Penggunaan buku komik "bahasa Indonesia bagi penutur asing (BIPA) 1" dan pengaruhnya terhadap hasil belajar peserta BIPA

One-Sample Kolmogorov-Smirnov Test

\begin{tabular}{|ll|r|}
\hline & & $\begin{array}{r}\text { Unstandardiz } \\
\text { ed Residual }\end{array}$ \\
\hline N & & 10 \\
Normal Parameters & Mean & $0 \mathrm{E}-7$ \\
& Std. Deviation & 6.73300329 \\
& Absolute & .204 \\
& Positive & .204 \\
Kolmogorov-Smirnov Z & Negative & -.156 \\
Asymp. Sig. (2-tailed) & & .644 \\
\hline
\end{tabular}

a. Test distribution is Normal.

b. Calculated from data

Berdasarkan hasil uji normalitas diatas dapat dilihat signifikansi 0,635 >0,05 makadapat disimpulkan data berdistribusi normal.

Berdasarkan hasil uji normalitas diatas dapat dilihat signifikansi 0,802 >0,05 makadapat disimpulkan data berdistribusi normal.

Tabel Levene's Test. Digunakan untuk menilai homogenitas tiap variabel

Tabel 9 Tes Levene

\section{Levene's Test of Equality of Error Variances $^{\text {a }}$}

Dependent Variable: Prestasi

\begin{tabular}{|l|l|l|l|}
\hline $\mathrm{F}$ & $\mathrm{df} 1$ & $\mathrm{df} 2$ & Sig. \\
\hline .546 & 7 & 72 & .796 \\
\hline
\end{tabular}

Tests the null hypothesis that the error variance of the dependent variable is equal across groups.

a. Design: Intercept + MetodeBelajar + MetodeUjian + MetodeBelajar *

MetodeUjian

Di atas menunjukkan nilai (Signifikansi) Sig. 0,796 di mana $>0,05$ sehingga bisa dikatakan varian antar group berbeda secara signifikan.

Tabel di bawah ini menunjukkan hasil dari uji Two Way Anova:

Tabel 10 Hasil Uji Anova Dua Arah

Tests of Between-Subjects Effects

Dependent Variable: Prestasi
\begin{tabular}{|l|r|r|r|r|r|}
\hline Source & $\begin{array}{c}\text { Type III Sum } \\
\text { of Squares }\end{array}$ & df & Mean Square & \multicolumn{1}{c|}{ F } & \multicolumn{1}{c|}{ Sig. } \\
\hline Corrected Model & $6695.000^{\mathrm{a}}$ & 7 & 956.429 & 11.289 & .000 \\
Intercept & 335405.000 & 1 & 335405.000 & 3958.879 & .000 \\
MetodeBelajar & 6480.000 & 1 & 6480.000 & 76.485 & .000 \\
MetodeUjian & 145.000 & 3 & 48.333 & .570 & .636 \\
MetodeBelajar * & 70.000 & 3 & 23.333 & .275 & .843 \\
MetodeUjian & & & & & \\
Error & 6100.000 & 72 & 84.722 & & \\
Total & 348200.000 & 80 & & & \\
Corrected Total & 12795.000 & 79 & & & \\
\hline
\end{tabular}

a. R Squared $=.523$ (Adjusted R Squared $=.477$ )

Dari tabel di atas, kita mendapatkan nilai-nilai penting yang bisa disimpulkan sebagai berikut: 
Corrected Model:

Pengaruh Semua Variabel independen (Metode Belajar, Metode Ujian dan Interaksi Metode belajar dengan Metode ujian atau "Metode Belajar*Metode Ujian") secara bersama-sama terhadap variabel dependen (Nilai Ujian). Apabila Signifikansi (Sig.) $<0,05$ (Alfa) $=$ Signifikan. Seperti di atas 0,000 berarti model valid.

Intercept:

Nilai perubahan variabel dependen tanpa perlu dipengaruhi keberadaan variabel independen, artinya tanpa ada pengaruh variabel independen, variabel dependen dapat berubah nilainya. Apabila Signifikansi (Sig.) $<0,05$

$($ Alfa $)=$ Signifikan. Seperti di atas 0,000 berarti intercept signifikan .

Media ajar:

Pengaruh metode belajar terhadap nilai ujian kemampuan berbahasa indonesia. Apabila Signifikansi (Sig.) $<0,05($ Alfa $)=$ Signifikan. Karena nilai sig di atas 0,005 berarti Media ajar berpengaruh signifikan .

Metode Ujian:

Apabila Signifikansi (Sig.) $<0,05$ (Alfa)= Signifikan. Karena nilai sig di atas 0,636 maka metode ujian tidak signifikan.

Media ajar*Metode ujian:

Pengaruh Media ajar dan metode ujian terhadap nilai ujian. Apabila Signifikansi (Sig.) $<0,05$ (Alfa)= Signifikan. Karena sig di atas 0,843 berarti media ajar dan metode ujian tidak signifikan.

\section{Simpulan}

Buku Komik BIPA 1 ini merupakan alternatif media pembelajaran BIPA yang menarik dan menyenangkan. Buku Komik BIPA 1 dapat menjadi solusi permasalahan komunikasi yang terjadi antara pengajar dan peserta di dalam kelas BIPA, khususmya pada tingkat prapemula. Tingkat prapemula adalah tingkat paling dasar yang ada di BIPA. Buku Komik BIPA 1 ini dapat menjadi jembatan bagi para peserta BIPA yang tidak menggunakan bahasa Inggris sebagai bahasa pertama mereka.

Berdasarkan hasil simulasi pembelajaran dengan kelas prapemula di BIPA Universitas Trisakti dapat disimpulkan bahwa media ini mampu memberikan pengalaman baru bagi peserta BIPA untuk belajar bahasa Indonesia dengan mudah dan menyenangkan. Mudah karena komik mampu menjembatani antara kosakata dalam bahasa Indonesia dengan gambar. Hal tersebut mempermudah peserta untuk mengingat dan menerapkannya ke dalam kehidupan sehari-hari. Menyenangkan karena peserta merasakan seolah mereka bermain sambil belajar sehingga tidak membebani. Setelah melakukann penelitian eksperimen dapat disimpulkan bahwa buku ajar BIPA dapat meningkatkan keterampilan berbahasa peserta BIPA.

\section{Ucapan Terima Kasih}

Pada bagian ini, tuliskan orang-orang yang membantu anda secara teknis saat penelitian dilakukan, seperti tempat penelitian, penyedia bahan penelitian, pengolahan data, penyandang/pemberi dana, atau orang-orang yang memberikan kritik membangun sebelum naskah diterbitkan. Jelaskan bagaimana orangorang tersebut berkontribusi. (11pt)

\section{Daftar Rujukan}

Brown, H. D. (1994). Teaching by Principles: An Interactive Approach to Language Pedagogy. Upper Saddle River. NJ: Prentice Hall Regents.

Daryanto. (2002). Media Pembelajaran. Yogyakarta: Gava Media. 
40 Penggunaan buku komik "bahasa Indonesia bagi penutur asing (BIPA) 1" dan pengaruhnya terhadap hasil belajar peserta BIPA

Eisner, W. (1986). Comics and Sequential Art. Florida: Poorhouse Press,

Hurlock, E. B. (2000). Child Development. Jakarta: Erlangga.

Masdiono, T. (2001). 14 Jurus Membuat Komik. Jakarta: Creativ Media.

McCloud, S. (2001). Understanding Comic. Jakarta: Kepustakaan Populer Gramedia.

McCloud, S (2008). Membuat Komik. Jakarta: PT Gramedia Pustaka Utama.

Oller, J. W. (1983). Story Writing Principles and ESL Teaching. TESOL Quarterly.

Sudjana, N. dan A. Rivai. 2001. Media Pengajaran. Bandung: CV Sinar Baru Bandung.

Sugiyono. (2001). Metode Penelitian Kualitatif Kuantitatif \& RnD. Bandung: Alfabeta,. 